\title{
One-pot synthesis of 2-aryl-1,2-fused pyrimidones
}

\author{
SAMIKANNU RAMESH ${ }^{\mathrm{a}}$, PON SARAVANAKUMAR ${ }^{\mathrm{a}}$, RAMASAMY DURAISAMYa, \\ ARVIND MATHUR $^{b}$ and PIRAMA NAYAGAM ARUNACHALAM ${ }^{a}, *$ \\ ${ }^{a}$ Biocon Bristol-Myers Squibb Research Center, Syngene International Pvt. Ltd., Biocon Park, \\ Plot No. 2 \&3, Bommasandra-Jigani Road, Bangalore 560 100, India \\ ${ }^{\mathrm{b}}$ Research and Development, Bristol-Myers Squibb, P.O. Box 5400, Princeton, New Jersey 08543, USA \\ Email: pn.arunachalam@syngeneintl.com
}

MS received 22 September 2016; revised 8 December 2016; accepted 29 January 2017

\begin{abstract}
A facile and versatile method for the synthesis of alicyclic fused pyrimidones from aminoacrylates and lactams in the presence of phosphorous oxychloride is described. The results suggest that this method is widely applicable except for cyclobutyl fused systems. This method gives better yield than the method of condensing aminopyrrolidines with the beta keto esters.
\end{abstract}

Keywords. Alicyclic fused pyrimidone; aminoacrylates; lactams; phosphorus oxychloride; cyclisation.

\section{Introduction}

Pyrrolopyrimidinone derivatives are ubiquitously found across a range of bioactive molecules. For example, TLR-9 antagonists takes advantage of the fused core structure of pyrrolopyrimidinone. This takes care of the selective corticotrophin-releasing factor-1 (CRF) receptor antagonism. ${ }^{1-4}$

In the course of our drug discovery program, we were interested in the rapid synthesis of 2-aryl substituted tetrahydropyrrolo $[1,2-a]$ pyrimidone derivatives as key templates (Figure 1). Initially we attempted to synthesize these targets through the condensation of the beta keto esters with the corresponding 2-amino3,4-tetrahydropyrrole derivatives as reported in the literature. ${ }^{5}$ This is shown in Scheme 1. However, this methodology required very long duration $(72 \mathrm{~h})$ for the synthesis of 2-amino-3,4-tetrahydropyrrole derivative that too with a poor yield of $10 \%$, besides, poorer yield for the condensation step itself (8\%).

We thought that a faster approach to the substituted fused pyrimidones $\mathbf{3}$ could be achieved by interchanging the reacting groups of both the reactants. That is to react a lactam $\mathbf{1}$ with an aminoacrylate $\mathbf{2}$ as shown in Scheme 2.

To support this view and to find a suitable reaction condition, keeping lactams as substrates, we searched the literature without much success. Broader search of the literature keeping the substituted pyrimidones as target molecules, led us to a couple of examples in which

*For correspondence the aminoacrylates were successfully condensed with, either the open chain alkyl chlorimines derived from the amides, ${ }^{6}$ or with the cyclised alkyl chloramines derived from the lactams which are same as the ones mentioned in our current study, ${ }^{7}$ to form the substituted 4-pyrimidones in good yields. The latter example, though resembled our present work, used phosphorous oxychloride as a solvent, was not an exhaustive one, and covered no more than four examples. In addition to these examples, we also came across an example in which 3-aminothiophene-2-esters were condensed with lactams in the presence of phosphorous oxychloride. ${ }^{8}$ Even though this example was not directly related to our present work; it did confirm the requirement of a chlorinating reagent such as phosphorous oxychloride to effect the condensation. These literature examples led us to think that the treatment of a lactam with the calculated quantity of phosphorous oxychloride in a suitable solvent would generate a cyclized chlorimine which could be reacted in situ with the aminoacrylates $\mathbf{2}$ to give the desired pyrimidone intermediates $\mathbf{3}$ as shown in the Scheme 3. This enabled us to synthesise a wide range of fused pyrimidones which were all hitherto not reported. Indeed, when we treated pyrrolidin2-one $(\mathbf{1 a}, \mathrm{n}=1)$ with phosphorous oxychloride, it did result in the formation of the corresponding cyclized chlorimine, ${ }^{9}$ intermediate $\mathbf{A}$ as evidenced by the GCMS of the reaction mixture. To confirm the reaction pathway, we carried out the addition of ethyl 3-amino3-(2-chloro-5-nitrophenyl) acrylate, 2a, to this reactive intermediate at ambient temperature and followed the reaction by LCMS. Over a couple of hours, this resulted 
<smiles>[R]C([AlH2])n1c([AlH2])nc(Br)cc1=O</smiles>

A

Figure 1. 2-aryl substituted tetrahydropyrrolo[1,2-a] pyrimidone.

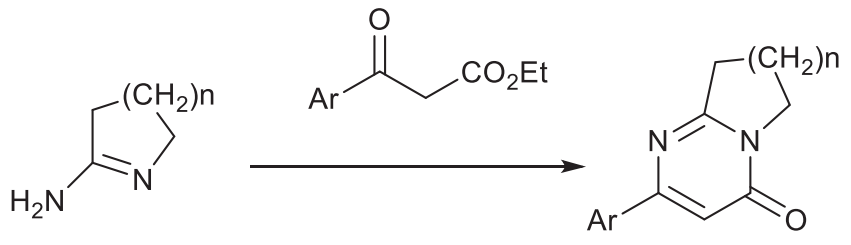

3

Scheme 1. Synthesis of fused pyrimidones via $\beta$-keto ester.

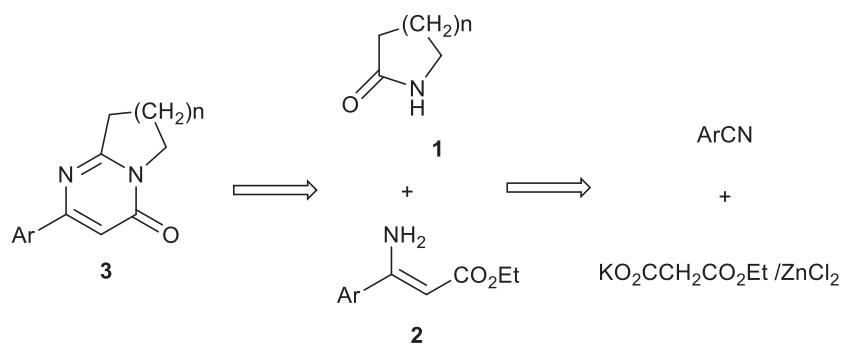

Scheme 2. Retrosynthesis of fused pyrimidone. in the formation of the adduct $\mathbf{B}$ as evidenced by the LCMS analysis of the crude reaction mixture. Though the intermediate $\mathbf{B}$ could not be isolated for further analysis due to its instability, upon heating at $90^{\circ} \mathrm{C}$ it was smoothly converted to 3aa. Based on these observations, it is clear that the nucleophilic attack of the aminoacrylates on the cyclic chloro intermediate $\mathbf{A}$, followed by the intramolecular condensation at the ester group at higher temperature resulted in the formation of pyrimidone derivatives 3aa as illustrated in Scheme 3.

This approach is attractive since a variety of aminoacrylates $\mathbf{2}$ could be easily synthesized via decarboxylative Blaise reaction from the arylnitriles, ${ }^{10-16}$ and can be condensed with lactams 1 of various ring sizes in the presence of phosphorous oxychloride. Using about 2.0 equivalents of phosphorus oxychloride instead of a large excess, ensures that a wider range of lactams with sensitive substitutions such as ester groups as in example $\mathbf{1 b}$ also can be successfully derivatized. As such, this methodology had the potential for synthesizing a large number of examples since we do not need to isolate the cyclic chlorimines which are not very stable as shown in Scheme 4.

\section{Experimental}

\subsection{Materials and instrumentation}

Melting points were recorded on Buchi melting point B-545 apparatus. ${ }^{1} \mathrm{H}$ NMR and ${ }^{13} \mathrm{C}$ NMR spectra were recorded on a 300/400-MHz Bruker DRX-400 instrument and DMSO-d6,<smiles>CCO/C=C(/N)c1cc([N+](=O)[O-])ccc1Cl</smiles>

Scheme 3. Possible reaction pathway for the synthesis of fused pyrimidones.<smiles>O=C1CNCN1</smiles>

1

$n=1,2,3$<smiles>[R]/C(N)=C/C(=O)OCC</smiles>

$\mathrm{R}=$ aryl, heteroaryl

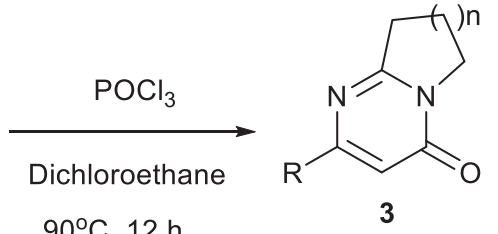

$90^{\circ} \mathrm{C}, 12 \mathrm{~h}$

$\mathrm{R}=$ aryl, heteroaryl

Scheme 4. General scheme for the preparation of 2-aryl-1,2-fused pyrimidones. 
$\mathrm{CDCl}_{3}, \mathrm{CD}_{3} \mathrm{OD}$ as solvents, wherever applicable, with tetramethylsilane (TMS) as an internal standard. Liquid Chromatography Mass Spectrometry (LC-MS) data were recorded on Agilent Technologies 1200 series.

2.2 Typical procedure exemplified by the synthesis of 2-(2-chloro-5-nitrophenyl)-7,8-dihydropyrrolo[1,2-a] pyrimidin-4(6H)-one (Table 1, Entry 1, 3aa)

A mixture of (ethyl 3-amino-3-(2-chloro-5-nitrophenyl) acrylate (200 mg, $0.739 \mathrm{mmol})$ (2a), 1,2-dichloroethane $(5 \mathrm{~mL})$, pyrrolidin-2-one (1a) $(62.9 \mathrm{mg}, 0.739 \mathrm{mmol}), \mathrm{POCl}_{3}(0.2 \mathrm{~mL}$, $1.5 \mathrm{mmol}$ ) was taken in a round bottom flask and stirred at $90^{\circ} \mathrm{C}$ for $12 \mathrm{~h}$ under nitrogen. After completion of the reaction, as monitored by the LCMS, the reaction mixture was cooled to room temperature. It was quenched with $10 \%$ sodium bicarbonate solution and extracted with ethyl acetate $(3 \times 25 \mathrm{~mL})$. The combined organic layers were washed with brine, dried over sodium sulphate, and concentrated on a rotary evaporator. The crude product was purified by ISCO chromatography on silica gel to give the pure product.

\subsection{Spectral data of selected compounds}

2.3a 2-(2-chloro-5-nitrophenyl)-7,8-dihydropyrrolo[1,2-a] pyrimidin-4(6H)-one (3aa): Light brown solid, $147 \mathrm{mg}$, $68 \%$ Yield; M.p. $184^{\circ} \mathrm{C} ;{ }^{1} \mathrm{H}$ NMR (300 MHz, CD $\mathrm{CD}_{3} \mathrm{OD}$ ): $\delta$ 2.17-2.52 (m, $\left.2 \mathrm{H},-\mathrm{CH}_{2}\right), 3.26(\mathrm{t}, J=7.9 \mathrm{~Hz}, 2 \mathrm{H}$, $\left.-\mathrm{CH}_{2}\right), 4.10-4.33\left(\mathrm{~m}, 2 \mathrm{H},-\mathrm{CH}_{2}\right), 6.66$ (s, $\left.1 \mathrm{H},-\mathrm{Ar}-\mathrm{H}\right)$, $7.82(\mathrm{~d}, J=9.1 \mathrm{~Hz}, 1 \mathrm{H},-\mathrm{Ar}-\mathrm{H}), 8.18-8.38$ (m, $1 \mathrm{H},-\mathrm{Ar}-$ $\mathrm{H}), 8.48(\mathrm{~d}, J=2.6 \mathrm{~Hz}, 1 \mathrm{H},-\mathrm{Ar}-\mathrm{H}) ;{ }^{13} \mathrm{C} \mathrm{NMR}(75 \mathrm{MHz}$, $\left.\mathrm{CD}_{3} \mathrm{OD}\right): \delta 168.05,163.75,161.88,140.30,139.74,133.30$, 127.29, 126.74, 113.99, 34.13, 20.27; (LCMS m/z (ESI); $292\left[\mathrm{M}^{+} \mathrm{H}\right]^{+}$; Anal. Calcd for $\mathrm{C}_{13} \mathrm{H}_{10} \mathrm{ClN}_{3} \mathrm{O}_{3}$ : C, 53.53; H, 3.46; N, 14.41\%. Found: C, 53.63; H, 3.59; N, 14.49\%.

Results for the remaining compounds are given in Supplementary Information

\section{Results and Discussion}

To optimize the reaction condition, we screened the amounts (in equivalents) of substrates and reagents as well as the reaction temperature. The best condition observed was as follows: 2-pyrrolidone (1a) (1 equiv.) and ethyl 3-amino-3-(2-chloro-5-nitrophenyl)acrylate (2a) (1 equiv.) in the presence of 2 equiv. of phosphorous oxychloride in ethylene dichloride was heated at $90^{\circ} \mathrm{C}$ for $12 \mathrm{~h}$ to afford the 2-(2-chloro-5-nitrophenyl)7,8-dihydropyrrolo[1,2-a]pyrimidin-4(6H)-one 3aa in $68 \%$ isolated yield (Table 1 Entry 1 ). With the above result in hand, we examined the reaction scope. As shown in Table 1, aryl amino acrylates, with both the electron donating as well as electron withdrawing

Table 1. One pot synthesis of 2-Aryl-1,2-fused pyrimidones.

\begin{tabular}{|c|c|c|c|c|c|}
\hline Entry & $\operatorname{Lactam}^{\neq}(\mathbf{1 a}-\mathbf{e})$ & $\mathrm{R}(\mathbf{2} \mathbf{a}-\mathbf{e})$ & Product $(\mathbf{3 a}-\mathbf{k})$ & Yield $(\%)^{a}$ & M.p. $\left({ }^{\circ} \mathrm{C}\right)$ Found/Reported \\
\hline 1 & $1 \mathrm{a}$ & $\mathbf{2 a}\left(2-\mathrm{Cl}, 5-\mathrm{NO}_{2} \mathrm{C}_{6} \mathrm{H}_{3}\right)$ & 3aa & 68 & 184.0 \\
\hline 2 & $1 \mathrm{a}$ & $\mathbf{2 b}\left(\mathrm{C}_{6} \mathrm{H}_{5}\right)$ & 3ab & 35 & $162.5 / 161.0^{17}$ \\
\hline 3 & $1 \mathrm{a}$ & $2 \mathrm{c}\left(4-\mathrm{Cl}, 2-\mathrm{F}-\mathrm{C}_{6} \mathrm{H}_{3}\right)$ & $3 a c$ & 57 & 168.8 \\
\hline 4 & $1 \mathrm{a}$ & 2d (7-azaindole) & 3ad & 38 & 181.0 \\
\hline 5 & $1 b$ & $\mathbf{2 a}\left(2-\mathrm{Cl}, 5-\mathrm{NO}_{2}-\mathrm{C}_{6} \mathrm{H}_{3}\right)$ & 3ba & 40 & 143.0 \\
\hline 6 & $1 \mathrm{c}$ & $\mathbf{2 b}\left(\mathrm{C}_{6} \mathrm{H}_{5}\right)$ & $3 \mathrm{cb}$ & 53 & $128.2 /\left(382 \pm 45 ; \text { B.p. } /{ }^{\circ} \mathrm{C}\right)^{18}$ \\
\hline 7 & $1 \mathrm{c}$ & $2 \mathrm{e}\left(4-\mathrm{F}-\mathrm{C}_{6} \mathrm{H}_{4}\right)$ & 3ce & 40 & 153.1 \\
\hline 8 & $1 \mathrm{c}$ & $\mathbf{2 f}\left(4-\mathrm{Br}-\mathrm{C}_{6} \mathrm{H}_{4}\right)$ & $3 \mathrm{cf}$ & 53 & 141.1 \\
\hline 9 & $1 \mathrm{c}$ & $2 \mathrm{~g}\left(4-\mathrm{COCH}_{3}-\mathrm{C}_{6} \mathrm{H}_{4}\right)$ & $3 \mathrm{cg}$ & 41 & 141.5 \\
\hline 10 & $1 \mathrm{c}$ & $2 \mathbf{h}\left(2-\mathrm{F}-\mathrm{C}_{6} \mathrm{H}_{4}\right)$ & $3 \mathrm{ch}$ & 58 & 138.2 \\
\hline 11 & $1 \mathrm{c}$ & $\mathbf{2 a}\left(2-\mathrm{Cl}, 5-\mathrm{NO}_{2} \mathrm{C}_{6} \mathrm{H}_{3}\right)$ & $3 \mathbf{c a}$ & 88 & 182.3 \\
\hline 12 & $1 \mathrm{c}$ & 2c $\left(4-\mathrm{Cl}, 2-\mathrm{F}-\mathrm{C}_{6} \mathrm{H}_{3}\right)$ & $3 c c$ & 56 & 159.1 \\
\hline 13 & $1 \mathrm{c}$ & $2 \mathbf{i}\left(3,4-\mathrm{F}-\mathrm{C}_{6} \mathrm{H}_{3}\right)$ & 3ci & 45 & 164.7 \\
\hline 14 & $1 \mathrm{c}$ & $\mathbf{2 j}(4-p y)$ & $3 \mathbf{c j}$ & 40 & $165.9 /\left(407 \pm 55 ; \text { B.p. } /{ }^{\circ} \mathrm{C}\right)^{19}$ \\
\hline 15 & $1 \mathrm{c}$ & 2d (7-azaindole) & $3 \mathrm{~cd}$ & 42 & 178.0 \\
\hline 16 & $1 d$ & $\mathbf{2 b}\left(\mathrm{C}_{6} \mathrm{H}_{5}\right)$ & $3 d \mathbf{d b}$ & 45 & $134.2 /\left(396 \pm 45 ; \text { B.p. } /{ }^{\circ} \mathrm{C}\right)^{20}$ \\
\hline 17 & $1 d$ & $2 \mathrm{e}\left(4-\mathrm{F}-\mathrm{C}_{6} \mathrm{H}_{4}\right)$ & 3de & 47 & $130.8 /\left(392 \pm 52 ; \text { B.p. } /{ }^{\circ} \mathrm{C}\right)^{20}$ \\
\hline 18 & $1 d$ & $2 \mathrm{~g}\left(4-\mathrm{COCH}_{3}-\mathrm{C}_{6} \mathrm{H}_{4}\right)$ & 3dg & 48 & 128.5 \\
\hline 19 & $1 d$ & $2 \mathbf{h}\left(2-\mathrm{F}-\mathrm{C}_{6} \mathrm{H}_{4}\right)$ & 3dh & 46 & 120.9 \\
\hline 20 & $1 \mathrm{~d}$ & $2 \mathrm{c}\left(4-\mathrm{Cl}, 2-\mathrm{F}-\mathrm{C}_{6} \mathrm{H}_{3}\right)$ & 3dc & 56 & 153.2 \\
\hline 21 & $1 d$ & $\mathbf{2 a}\left(2-\mathrm{Cl}, 5-\mathrm{NO}_{2} \mathrm{C}_{6} \mathrm{H}_{3}\right)$ & 3da & 71 & 192.8 \\
\hline 22 & $1 d$ & $\mathbf{2 i}\left(3,4-\mathrm{F}-\mathrm{C}_{6} \mathrm{H}_{3}\right)$ & 3di & 51 & 118.5 \\
\hline 23 & $1 d$ & 2k (2-pyrimidin) & 3dk & 36 & 143.7 \\
\hline 24 & $1 d$ & 2d (7-azaindole) & 3dd & 40 & 153.5 \\
\hline 25 & $1 \mathrm{e}$ & $\mathbf{2 a}\left(2-\mathrm{Cl}-5-\mathrm{NO}_{2} \mathrm{C}_{6} \mathrm{H}_{3}\right)$ & 3ea & 32 & 175.3 \\
\hline
\end{tabular}

F (1a) pyrrolidin-2-one; (1b) ethyl 5-oxopyrrolidine-2-carboxylate; (1c) piperidin-2-one; (1d) azepan-2-one; (1e) 3,4dihydroisoquinolin-1(2H)-one. ${ }^{a}$ Isolated yield. 
<smiles>CCOC(=O)C1CCc2nc(-c3cc([N+](=O)[O-])ccc3Cl)cc(=O)n21</smiles>

Figure 2. 2-aryl substituted tetrahydropyrrolo[1,2-a] pyrimidones.

substituents, gave satisfactory yields. However, the lactam ring size played a crucial role. Improved yields were observed with the increase in the size of the lactam ring with the six membered lactams generally giving better yields than the five membered lactams for the same aminoacrylate. However, the seven membered lactam gave marginally lower yield than the six membered lactam but more than the five membered lactams, as shown in the example of $\mathbf{3 d b}$. No product formation was observed with the four membered lactam under the same set of reaction conditions, presumably due to the ring strain associated with the cyclisation step. To check the generality of this method, we also tried a lactam with the ester functionality. This gave the corresponding pyrrolopyrimidine ester $\mathbf{3 b a}$ in a moderate yield of $40 \%$. We extended this methodology to a bicyclic lactam 1e which gave the corresponding tricyclic pyrimidone 3ea in $32 \%$ yield. Both these are the exceptions and are represented in the Table 1 as entries $\mathbf{5}$ and $\mathbf{2 5}$ as well as in Figure 2.

\section{Conclusions}

In summary, we have developed a convenient procedure for the synthesis of alicyclic fused pyrimidone. While the condition is not suitable for the synthesis of cyclobutyl fused pyrimidone derivatives, this method gives quick access to other variously substituted pyrrolopyrimidones in moderate to high yields. Currently, this is a better alternative to the existing methodology of reacting the aminopyrrolidines with the beta keto esters.

\section{Supplementary Information (SI)}

Characerization data and Figures S1-S25 for all the compounds are provided in the Supplementary Information which is available at www.ias.ac.in/chemsci.

\section{Acknowledgements}

Authors thank Department of Discovery Analytical Services of Biocon Bristol-Myers Squibb Research Center for their valuable support and, Jianqing Li, Richard Rampulla and Bei Wang of Bristol Myers Squibb for logistic help.

\section{References}

1. Roberto A, Roberto B, Giorgio B and Anna M C 2007 Cyclopenta[d]pyrimidines and dihydropyrrolo[2,3d]pyrimidines as potent and selective corticotropinreleasing factor 1 receptor antagonists Chem. Med. Chem. 2528

2. Chen C, Wilcoxen K M, Huang C Q, Xie Y-F, McCarthy J R, Webb T R, Zhu Y-F, Saunders J, Liu X-J, Chen T-K, Bozigian H and Grigoriadis D E 2004 Design of 2,5Dimethyl-3-(6-dimethyl-4-methylpyridin-3-yl)-7-dipropylaminopyrazolo[1,5-a]pyrimidine (NBI 30775/R121919) and Structure-Activity Relationships of a Series of Potent and Orally Active Corticotropin-Releasing Factor Receptor Antagonists J. Med. Chem. 474787

3. Michael C L, Yili, David L S, Maureen K S, Amy N F, Wei L, Richard L W, Kofi A O, Christopher D E, Mark W B, Steven V O, John A W and Thomas 2005 Synthesis and evaluation of tricyclic pyrrolopyrimidinones as dipeptide mimetics: Inhibition of interleukin$1 \beta$-converting enzyme P D Bio. Med. Chem. Lett. 15 4322

4. Bashir A D, Praveen P, Sunil K, Mohammad A W, Akshay K S, Parduman R S, Sanjay P, Meena S and Baldev S $2013 \mathrm{Fe}-\mathrm{Al} /$ clay as an efficient heterogeneous catalyst for solvent-free synthesis of 3, 4dihydropyrimidones J. Chem. Sci. 125545

5. Steve C, Chris Y, Stuart F, Gareth B, John B, Osamu I, Elise G, Anthony R, Takashi K, Akira I, Shingo N, Ryo $\mathrm{S}$ and Sho K 2013 Pyridinone and pyrimidinone derivatives as factor xia inhibitors Int. Appl. WO2013093484 A1

6. Benjamin S and Henry S 1956 A new synthesis of $2: 3$ : 5 : 6-substituted 4-pyrimidones J. Chem. Soc. 4708

7. Oripov E O, Zakhidov K A and Shakhidoyatov Kh M 1991 Synthesis of bicyclic analogues of deoxyvasicinone Chem. Nat. Comp. 27341

8. Abdillahi I and Kirsch G 2011 Synthesis of a Series of Novel Thieno- and Benzothieno[3,2- $d$ ]pyrimidin4(3H)-ones Synthesis 1314

9. Rokach J, Hamel P, Hunter N R, Reader G and Rooney C S 1979 Cyclic amidine inhibitors of indolamine Nmethyltransferase J. Med. Chem. 22237

10. Blaise E E 1901 New reactions of the organo metal derivatives C.R. Hebd. Seances Acad. Sci. 132478

11. Lee J H, Choi B S, Chang J H, Lee J B, Yoon J Y, Lee J and Shin H 2007 The Decarboxylative Blaise Reaction J. Org. Chem. 721026

12. Toussaint O, Capdevielle P and Maumy M 1986 The Copper(I)-catalyzed decarboxylation of malonic acids; A new mild and quantitative method Synthesis 1029

13. Darensbourg D J, Holtcamp M W, Khandelwal B and Reibenspies J H 1994 Intramolecular and intermolecular hydrogen-bonding in triphenylphosphine derivatives of Copper(I) carboxylates, $\left(\mathrm{Ph}_{3} \mathrm{P}\right)_{2} \mathrm{CuO}_{2} \mathrm{C}\left(\mathrm{CH}_{2}\right) \mathrm{nCOOH}$. 
Role of copper(I) in the decarboxylation of malonic-acid and its derivatives Inorg. Chem. $\mathbf{3 3} 531$

14. Hassner A and Stumer C 2002 In Organic synthesis based on name reactions $2^{\text {nd }} \mathrm{Ed}$. (Oxford: Elsevier)

15. Mundy B P, Ellerd M G and Favaloro F G 2005 In Name reactions and reagents in organic synthesis (Canada: Wiley Interscience)

16. Rao H S P, Rafi S and Padmavathy K 2008 The Blaise Reaction Tetrahedron 648037

17. Andre E, Andre L B and Christian R 1966 Synthesis of pyrrolopyrimidinones from 2-amino-1-pyrroline 1966 C. R. Sean. Acad. Sci., Serie. C: Sci. Chim. 262365
18. Jozsef V, Pal K, Miklos J and Gyorgy S 1988 Effect of changes in phase composition on retention values. I. Reproducibility of RMO values in open and closed chromatographic systems Acta Pharm. Hung. 588

19. Aude F, Thierry G, Alistair L, Mourad S, Corinne V and Assignee Y P 2008 Sanofi-Aventis, Fr.; Mitsubishi Tanabe Pharma Corporation, substituted heteroaryl pyridopyrimidone derivatives WO 2008078196

20. Grigoryan N P, Tarzyan L A, Markosyan A I, Paronikyan R G and Sukasyan R S 2011 Synthesis and psychotropic activity of 5-cyclohexyl-5-methyl2-sulfanyl-3,4,5,6-tetrahydrobenzo[ $h]$ quinazolin-4-one Pharm. Chem. J. 4579 